\title{
Når størrelsen teller!
}

Fredag 31. oktober disputerte Beate Horsberg Eriksen ved Ålesund sjukehus for ph.d.-graden ved Norges teknisk-naturvitenskapelige universitet i Trondheim med avhandlingen:

„Hjertefunksjon hos spedbarn under postnatal omstilling og ved videre modning. En longitudinell ekkokardiografisk studie av premature og terminfødte spebarn".

Nyfødte, og spesielt for tidlig fødte barn, er sårbare og har risiko for forstyrrelser $\mathrm{i}$ reguleringen av hjertefunksjon og kretsløp.

Avhandlingen inneholder tre studier som vurderer hjertemuskelfunksjonen hos premature barn og barn født til termin med hjelp av pulsed wave vevs-Doppler, konvensjonell og farge-vevs-Doppler. Repeterte undersøkelser for hvert barn ble utført for å kunne studere dynamiske endringene i hjerte- og karsystemet.

De første to artiklene omhandler ekkokardiografiske undersøkelser hos spedbarn født 5-9 uker før termin. Disse målingene ble utført på dag 1, 2 og 3 etter fødselen og ved tidspunktet for ultralydterminen. Målingene for hjertemuskelfunksjonen holdt seg forholdsvis stabile gjennom de tre første dagene og økte kraftig ved termintidspunktet.

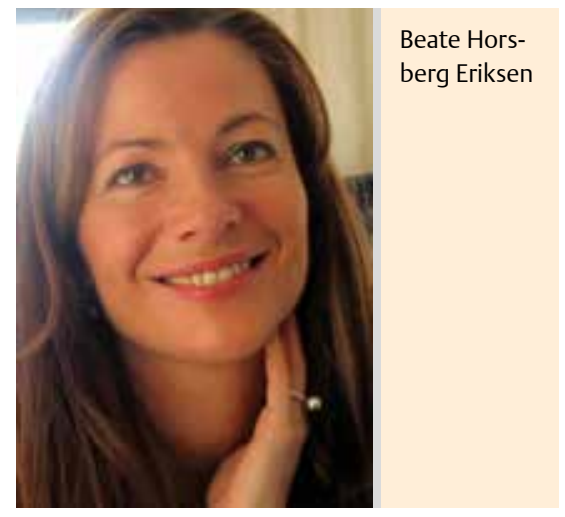

Den tredje artikkelen sammenlignet hjerteundersøkelsene fra dag 3 og ved forventet termin hos de for tidlig fødte barna med tilsvarende hjerteundersøkelser hos friske barn ved tre dagers alder samt 1220 uker etter fødselen. Ut fra resultatene hadde for tidlig fødte barn ikke redusert hjertefunksjon ved termintidspunktet når ulikheter i hjertestørrelse ble tatt i betraktning.

De valgte parameterne for bedømming av hjertemuskelfunksjonen var mål- og reproduserbare.

På bakgrunn av disse funnene anbefales det å ta hensyn til barnets svangerskapsalder ved fødsel, barnets alder etter fødselen samt hjertestørrelsen når hjertemuskelfunksjonen skal vurderes hos spedbarn med ulik alder og størrelse. 